\title{
METHODS OF DETERMINATION THE INTERIOR POTENTIAL OF ENTERPRISE IN MAKING STRATEGICAL ASSORTMENT DECISIONS
}

\author{
Svitlana MALYUK', \\ Mykolaiv Institute of Law, National University of Odessa Law Academy, Ukraine
}

\begin{abstract}
The analysis of the internal environment of the enterprise is aimed at assessing the strategic potential of the enterprise as a whole and its individual functional subsystems. The efficient activity of enterprise cannot be realized without a systematic definition and using the existing capabilities since, as a rule, the potential of the organization is higher than its actual implementation. It is not possible to put forward long-term goals, to form the most optimal strategy to achieve them without the characteristics of accumulated enterprises potential. From this point, the purpose of the paper is to study and establish the criteria that characterize the inner potential of the company during the implementation of assortment strategies. The method of evaluating of these indicators, as well as the selection of the assortment strategy according to the results has been suggested. Methods. The research of the internal potential of PJSC "Mykolaiv bakery № 1" is based on the expert questionnaire, which made it possible not only to identify a number of criteria for internal enterprises environment, which made it possible not only to identify a number of criteria for internal environment, as well as by experts to determine the parameter and boundary values of coefficients influencing the choice of the assortment strategy. The results of questionnaire showed that the main criteria of the characteristics of the internal potential of the company are: primary phases of the life cycle of the goods (were determined on the basis of the matrix "Market growth Market Share"); prospects of producing the assortment groups of goods (calculated using the integral coefficient of goods assortment); changes in sales amount (described by trigonometric dependencies); degree of the goods assortment realization (evaluated using the coefficient of realization); assortments balance according to the Pareto rule (based on the Pareto rule, as well as expert survey); the level of liquidity and solvency of the company (calculated using the absolute liquidity ratio). Depending on the obtained limited parameters of coefficients were proposed following assortment strategies: a strategy for the elimination of the goods (the selection of such products, which look dubious from the point of view of the further attractiveness on the market and have to be re-certificated); the strategy of product differentiation (the process of developing a number of significant modifications of the product that make it different from the competitors goods), goods diversification strategy (production of additional products that will be offered to the new markets), a strategy of goods variations (based on a strategy of increasing the concentration of consumer's usefulness effect from the using of goods). The practical significance. The research of the indicators of the internal potential of the enterprise allows to assess the internal strengths and weaknesses of the production realistically, to look for reserves, and therefore, to choose the optimal assortment strategy that will enable the company to maintain the level of competitiveness, and strengthen their competitive position in the industry. Value/originality. Obtained during research information can provide marketers of the investigated enterprise with more accurate information, received on the basis of a scientific approach that in prospect will allow to form effective assortment strategies.
\end{abstract}

Key words: internal potential of the enterprise, assortment strategy, product life cycle, the prospects of production assortment, the change in sales volume, the index of assortments realization, assortments balance, the level of liquidity and solvency.

JEL Classification: M31, L15, L69

\footnotetext{
Corresponding author

${ }^{1}$ Department of Humanitarian Subjects, Mykolaiv Institute of Law, National University of Odessa Law Academy.

E-mail: SvAlMalyuk@i.ua
} 


\section{Introduction}

Analysis of the internal environment of enterprise is aimed at strategic potential assessment of the company as a whole and its individual functional subsystems. Effective enterprise activity cannot be carried out without systematic estimation and use of existing resources, so far as the enterprise potential is usually higher than level of its actual implementation. Without characteristics of accumulated potential of the company it is impossible to impose perspective goals, develop the most appropriate strategy to achieve them. While using the systematic approach to analyze the internal environment, it is appropriate to interpret it as interior potential of enterprise, which is a system of interrelated elements that carry out certain functions during the process of providing manufacture of products and achieving other enterprises goals.

During researching the interior potential of PJSC "Mykolaiv bakery № 1" we have conducted expert questionnaire, which allowed identifying criteria for evaluating the internal environment.

The aim of our research is reasoning criteria that characterize the inner potential of the company in the implementation of assortment strategies, values and class limits of values and choosing the assortment strategy according to the achieved results of the evaluation of these indicators.

\section{Preferential phases of product life cycles}

Preferential stages of product life cycles, included in the assortment nomenclature, which lets out by the enterprise we determine on basis of the matrix "Market growth market share":

\begin{tabular}{|c|c|c|c|}
\hline & Share of the assortn & terprise trade turnover & \\
\hline 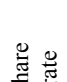 & $\begin{array}{l}\text { II - LC phase } \\
\text { increase }\end{array}$ & $\begin{array}{l}\text { I - LC phase } \\
\text { implantation }\end{array}$ & 햅 \\
\hline 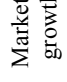 & $\begin{array}{l}\text { III - LC phase } \\
\text { saturation }\end{array}$ & $\begin{array}{l}\text { IV - LC phase } \\
\text { decrease }\end{array}$ & za \\
\hline & High & Low & \\
\hline
\end{tabular}

Adapted by the author (Evans, 2002; Aaker, 2007)

Fig. 1. Distribution of the enterprises product assortment in phases of the life cycle

High growth rate (Tpj) is considered to be higher than market average:

$$
T_{p j}=\frac{O p_{j}}{\sum_{j=1}^{n} O p_{j}} * 100 \%,
$$

where Opj - average monthly amount of product realization of $j$-s enterprise;

$\sum O p_{j}$ - total amount of average monthly product realization $\mathrm{n}$-th number of enterprises in the industry during the reporting period.

Assortment share of group $\mathrm{D}_{\mathrm{pi}}$ in enterprises trade turnover, which is higher than average share for the company, conforms to the high market share:

$$
D_{p i}=\frac{\text { TOc.M. } i}{\sum_{j=1}^{n} T O C . \text {. .. } i} * 100 \%
$$

where TOc.M.i - average monthly amount of trade turnover in i-th group;

$\sum$ TOC.M.i - total amount of average monthly trade turnover n-th number of assortment groups for the period.

Preferential phase of assortment production LC, according to (Karpenko, 2009), defines the availability of own funds to invest into the assortment restoration. The bigger is the number of "cash cow" in the assortment bag and their specific weight in trade turnover, the higher are the investment abilities, because they are "the main contributors to the resources accumulation for developing products on the fast -growing markets "( Zvjaginceva, 2009).

During researching we have reached the next conclusions about the assortment decisions of enterprise in context of the assortment products life cycle:

1. On the implantation and decrease phase we recommend to remove a part of the least promising goods from production and try to increase the revenues from the most promising goods by changing the outlet or creating modifications, changing the design, packaging etc.. These will ensure the extension of the life cycle at minimum costs.

2. On the increasing phase one should create extra assortment proposal modifications based on the existing or improved technology of producing goods, which are on the saturation stage.

3. On the saturation phase it is reasonable to invest into the creation of the newest assortment proposals (that can be the basis of the goods line ), or make goods with improved consumer properties.

\section{Prospects of producing the assortment groups of goods}

To rate this index can be used integral coefficient of assortment goods prospects according to all of the suggested specifications, proposed by Putyatina L.M.:

$$
K i^{\text {nep }}=\sum_{j=1}^{s} \Pi i j * \varphi_{j}
$$

where $\Pi i j$ - index of $\mathbf{j}$-criteria of prospect according to the i-th assortment group of goods;

$\varphi_{j}$ - weight coefficient of j0criteria of prospect significance;

$\left(\sum \phi \mathrm{i}=1\right)$, deterring by expert assessments during the questionnaire; $s$ - perspective criteria amount.

Experts took 3 main indexes as the basis of prospects of producing the assortment groups of goods:

- assortment group part in goods realization amount;

- assortment group part in paying off defrayal;

- profitability of producing the assortment group of goods.

We determine the contribution of assortment group in paying off defrayal through establishing correlation between the total expenses for producing goods and 
amount of turned out goods, distributing constant and variable components using the method of linear regression. Distributing expenses is necessary for correct analyzing the costs. Thus, in terms of part-charging facilities, financial results of the enterprise might deteriorate, as the result of making decisions to withdraw from production goods with the low level of paying off defrayal (unprofitable at costs ),but with no positive margin profit. Correlation between costs and production scope is described by the following formula:

$$
03_{i}=C_{i}+\Pi_{i} \times N_{i}
$$

where $i$ - assortment group of goods;

$C_{i}$ - stable expenditure, which refer to the $i$-th assortment group of goods (expenditure for maintenance facilities, general shops goods expenditure, general plants expenditure);

$\Pi_{i}-$ rate of variable expenditure for one produced commodity;

$N_{i}$ - amount of producing the $i$-th assortment group of goods;

$O 3_{i}$ - general costs for producing the $i$-th assortment group of goods.

We determine the contribution of each assortment group in paying off defrayal of enterprise by the formula:

$\mathrm{P}_{\mathrm{i}}=Ц_{\mathrm{i}}-\Pi_{\mathrm{i}}-\mathrm{C}_{\mathrm{i}} / N_{\mathrm{i}}$,

where $P_{i}$ - amount of the income from realization of the $i$-th assortment group of goods.

In terms of full realization of produced goods the role of profitability index of assortment group of goods is indisputable. However, often unrealized commodity accumulates in the enterprises storehouse. In that terms, the index of profitability is not enough. It is necessary to enter a relative index of profitability - profitableness of goods producing, which characterize the return from funds invested in production. We suggest to determine the profitability index (Riнi) by the following formula:

$R_{\text {iні }}=\mathrm{C}_{\mathrm{i}} \times N_{\mathrm{i}} /\left(\mathrm{C}_{\text {зал }}+\mathrm{C}_{\text {витр }}\right)$,

where $C_{3 a 1}$ - the sum of unrealized commodity for the beginning of the period;

$C_{\text {вump }}$ - the sum, spent on the output of the assortment group in the analyzing period.

We determined the limiting values of integral coefficient of assortment groups prospectiveness in accordance with expert opinions in the questionnaire.

As the result, the following strategic assortment decisions are determined in the context of limited coefficient values the assortment groups prospectiveness :

1. Under $K_{i}^{\text {nep }}<0,2$ the degree of assortments prospectiveness is low, so one should take out from production a part of the least promising assortment positions and try to increase the income from the most promising goods due to the changes of the market or creating modifications, changing design, packing etc.. Under the minimal expenses these measures will ensure the prolongation of the goods life cycle.

2. 0,2 $\leq K_{i}^{\text {nep }}<0,6$ demonstrates the medium assortments prospectiveness level. In this case we suggest to create extra modifications of assortments proposals on the basis of improved technology of producing goods, which are on the stage of satiation.

3. $K_{i}^{\text {nep }}>0,6$ indicates the high level of assortments prospectiveness. In this case one should invest into creation substantially new assortment positions (that can be the basis of the goods line), or create goods with improved consumer capabilities.

\section{Change of the sales amount}

If we assess the dynamics of sales, the change in indexes of periods is unsustainable. Thus, the best reflection of seasonal demands character, which is accentuated in some articles (Balabanova, 2006; Zvjaginceva, 2009), is by trigonometric dependencies.

We are interested only in the general tendencies of amount sales changes (increasing and decreasing) in absolute display, compared to the rate of market development. There is meaning to describe these tendencies by using the the tangent of slope angle of the lineal trend to the axis OX (first derivative of a linear trend in time) (Kovtun, 2009). Take this statement as a basis. To find the equations of linear regression use the method of least squares. Then the regression equation will look like this:

\section{$Y=k \times X+b$}

where $k$-tangent of slope angle of the regression line to the axis OX; $X$ - months, $(1,2, \ldots 12) ; b$ - constant; $Y$ the sales amount in natural or money display (or the part in sales amount).

For finding the lineal trend of sales amount subordination (or markets parts) to time, we use the system of normal equations:

$$
\left\{\begin{array}{l}
n \times b+k \times \Sigma X_{i}=\Sigma y_{i} \\
b \times \Sigma X_{i}+k \times \Sigma\left(X_{i}\right)^{2}=\Sigma X_{i} \times Y_{i}
\end{array}\right.
$$

Thence deduce:

$$
\mathrm{k}=\left(n \times\left(\sum X_{i} \times Y\right)-\Sigma X_{i} \times \Sigma y_{i}\right) /\left(n \times \Sigma\left(X_{i}\right)^{2}-\Sigma\left(X_{i}\right)\right)
$$

This criteria lets us to qualify the dynamic of changing the relative part of enterprises market, which helps to form an opinion about changes in competitive positions, and the higher they are, the bigger opportunities ones have to put into the optimization of the assortment set, to differentiate assortment strategic decisions.

According to the dynamic of changing part of enterprises market, we suggest to make the following decisions:

1. Under $k<0$ one can see the decrease of the sales amount, so it is reasonable to take out from production a part of the least promising assortment positions and try to increase the income from the most promising goods due to the changes of the market or creating modifications, changing design, packing etc. ... The firm loses its markets positions, so one should use the assortment strategies, and their realization will lead to pause the sales amount decrease, in other words will let to stabilize the state in short terms and with the minimal expenses.

2. $0<k<K c e p$ shows us the positive increasing temps of sales, but they still are lower, than markets average. So it is necessary to create extra assortment positions 
modifications, on the basis of existing or improved technology of producing goods, which are on the stage of satiation. The firm realizes goods at the lower level of sales amount, than markets average, so product modernization becomes the priority direction in realization of assortment strategies.

3. Under $k>K c e p$ the dynamic of sales amount is higher than markets average. In this case the firms positions are stable, they can work for the perspective, so one should invest into creation substantially new assortment positions (that can be the basis of the goods line), or create goods with improved consumer capabilities and advance them to the new markets.

\section{The level of realization of goods assortments of the enterprise}

To our mind, firstly, the levels of realization of goods assortments of the enterprise represent markets demand on the enterprises production, and also characterize sales amount and output for the assortment position of the enterprise. We suggest estimating the levels of realization of goods assortments of the enterprise by the realization coefficient (Kpi):

$$
K p i=\frac{3 a r_{i}}{Q n n p},
$$

where $3 a \wedge_{._{i}}$ - the remnant in natural expression of the assortment group and for the end of the realization period;

Qnnp - the output of the same assortment group in natural expression during the period.

For the goods, for which the "accumulation of finished products" policy is not used for further realization (seasonal, contractual, etc.), coefficient Kpi characterizes the level of the demand for the produced good.

Limit values of realizability are set by an expert way during the questionnaire. As the result in the context of limited values of the realization coefficient were made the next decisions:

1. Under Kpi < 0,2 commodity is in high demand. So there is a possibility to invest into creation modernized and fundamentally new assortment positions, or increasing the sales amount by changing the appearance and advancing them to the already mastered markets.

2. Under $0,2 \leq K p i<0,4$ commodity is in medium demand. In this case it is expedient to work on the improving the consumer properties of the less successful goods, or increasing sales amount by changing their functional options. One should modify the existing assortment positions, bring them to the new markets, herewith producing technology can either change or not to change.

3. Under $0,4 \leq K p i<1$ there is difficult goods selling. In this case we emphasize the necessity of improving production technology of assortment of manufactured goods.

4. Under Kpi $\geq 1$ commodity is not in demand, so one should reduce assortment by identifying unprofitable product lines positions and take them out of production, or change the strategic area of sales of existing product assortment.

\section{The balance of the assortment by the Pareto rule}

The balance of the assortment ("product bag") by the Pareto rule is defined by what part of the assortment positions (leader of sales) provides $80 \%$ of turnover. The most balanced "bag" will be those, which provides the ratio of $80 / 80$ (Mis'ko, 2010), the ratio of $80 / 20$ is considered to be critical for the enterprise, which means that $80 \%$ of assortment positions ensures only $20 \%$ of trade turnover, in other words the biggest part of goods in "bag" doesn't succeed at the market and should be taking out from producing. The bag is more balanced when is its parts are more evenly distributed between goods in the turnover.

Experts' thoughts about the «assortment bags" level of balance came to the fixed parametric values and the level of its index. But we have defined the assortment strategic decisions by scale evaluation of "assortment portfolios" balance by the Pareto rule:

1. 80/ (65-80) - high level of assortments balance, so there is a possibility to invest into creation fundamentally new assortment positions and advancing them to the already mastered or new markets.

2. 80/ (30-65) - medium level of assortments balance. One must work on the improving the consumer properties of the less successful goods, or increasing sales amount by changing their appearance.

3. 80/( AO 30) - low level of assortments balance, which needs to improve the producing technology of assortment, that turns out by enterprise and reduce the assortment by finding out unprofitable assortment positions and taking them out of producing, or changing the strategic sales area of existing product range.

\section{The level of liquidity and solvency}

The level of liquidity and solvency characterizes enterprises ability to attract credit resources to implement this or that assortment strategy. From a financial point of view the solvency is an indicator of the ability to repay the debt obligations in time, including loans, taken from bank (Balabanova, 2006). The higher solvency is, the greater the possibility of obtaining loans.

As the index, that characterizes solvency (liquidity) of enterprise, the majority of experts chose the absolute liquidity ratio (Ka.s.). It shows what part of the shortterm loan obligations can be immediately repaid, if it is necessary (Kanischenko, 2007). Calculate the absolute liquidity ratio by the formula:

$\kappa_{\text {а.л. }}=$ ДС $/ К 3$,

where $A C$ - firms costs;

$K 3$ - short-term debts, including short-term loans and credits, settlements with creditors etc.

Recommendatory lower limit of indicator set in western literature - 0.2. In home practice, usually, the actual average values of the coefficient, much lower the values mentioned 
in western literature (Evans, 2002; Aaker, 2007), that's why the limits of intervals of values of this indicator, corresponding to low, medium and high level of solvency, we determine by experts.

Experts' thoughts about the assessment of liquidity level came to fixed parametric values for this indicator. And we determined strategic assortment decisions for each of them in the context of intervals of coefficient values of absolute liquidity of the company:

1. Under Ka.ı. > 06 enterprise gets the high level of solvency. We recommend to invest into into creation substantially new assortment positions (that can be the basis of the goods line), or create goods with improved consumer capabilities, by changing their structural content. Financial abilities of the firm are stable, so one can work for perspective.

2. Under 0,2 <Ka.s. $<0,6$ - level of solvency is medium. середній. At this time the financial position of the company requires stronger actions, aimed at creating extra modifications of assortment positions, on the basis of existing or improved technology of producing goods.
3. Under Ka.^. < 0, 2 level of solvency is low. In order to improve the financial situation of the company it is needed to choose the implementation of low-cost assortment strategies. One should take out of producing a part of the least promising assortment positions and try to increase the income from the most promising goods due to the changes of the market or creating modifications, changing design, packing etc.

\section{Conclusions}

During the research we have substantiated the basic criteria of the characteristics of internal potential of enterprise, which are important in the formation of the assortment strategy, and suggested the method of evaluation of these indicators and selection of assortment strategy according to results. We offered the results of the research the marketing department of PJSC "Mykolaiv bakery № 1 " for implementation in practice. The aim of the following research is evaluation of indicators of the external enterprises potential.

\section{References}

Aaker, D. (2007). Strategic market management. St. Petersburg, 2007. - 496 p.

Balabanova, L. \& Holod, V. (2006). Marketing management of competitiveness of enterprises, strategic approach. Donets'k, 2006. 294 p.

Evans, J. (2002). Marketing. Sirin, 2002. 308 p.

Kanischenko, O. (2007). International Marketing at Ukrainian enterprises' activity. Kyiv, 2007. - 448 p.

Karpenko, J. (2009). Flour-milling plants extremely need modern approaches to planning in nowadays. Grain and bread, 4: 21-25.

Kovtun, O. (2009). The competitiveness of the enterprise: strategic context. Lviv, 2009, 276 p.

Mis'ko, G. (2010). Methodological approaches to assessing the economic strategy of the food industry in a competitive environment. The Messenger of ZNU, 4: 61-67.

Putyatin, A. \& Putyatina, L. (1998). Strategy and tactics of developing the enterprise in a competitive environment. Industrial policy: theory and practice, 2: 57-67.

Zvjaginceva, O. (2009). Marketing commodity policy of the bakery. The Messenger of SAU, 2: 46-52.

\section{Светлана МАЛЮК}

\section{МЕТОДИКА ОЦЕНИВАНИЯ ВНУТРЕННЕГО ПОТЕНЦИАЛА ПРЕДПРИЯТИЯ ПРИ ПРИНЯТИИ} АССОРТИМЕНТНЫХ СТРАТЕГИЧЕСКИХ РЕШЕНИЙ

Аннотация. Анализ внутренней среды предприятия направлен на оценку стратегического потенциала предприятия в целом и отдельных его функциональных подсистем. Эффективная деятельность предприятия не может осуществляться без систематического определения и использования существующих возможностей, поскольку потенциал организации как правило выше уровня его фактической реализации. Без характеристики накопленного потенциала предприятия невозможно выдвигать перспективные цели, формировать наиболее оптимальную стратегию их достижения. Исходя из этого, целью работы является исследование и обоснование критериев, которые характеризуют внутренний потенциал предприятия в процессе реализации ассортиментных стратегий. Предложена методика оценивания данных показателей, а также выбор ассортиментной стратегии в соответствии с полученными результатами. Методика. Исследование внутреннего потенциала ПАО «Николаевский хлебозавод № 1» основано на экспертном анкетном опросе, что позволило не только выделить ряд критериев внутренней среды предприятия, а также, с помощью экспертов определить параметрические и граничные значения коэффициентов, влияющие на выбор ассортиментной стратегии. Результаты опроса показали, что основными критериями характеристики внутреннего потенциала предприятия являются: преимущественные фазы жизненного цикла товаров (были определены на основании матрицы «Рост рынка - Доля рынка»); перспективность производства ассортиментных групп товаров 
(рассчитывалась с использованием интегрального коэффициента перспективности ассортимента товаров); изменения объемов продаж (описаны с помощью тригонометрических зависимостей); степень реализованности ассортиментов продукции (оценивали с помощью коэффициента реализованности); сбалансированность ассортимента по правилу Парето (за основу взято правило Парето, а также опрос экспертов); уровень ликвидности и платежеспособности предприятия (рассчитывался с помощью коэффициента абсолютной ликвидности). В зависимости от полученных граничных показателей коэффициентов были предложены следующие ассортиментные стратегии: стратегия элиминации товара (выделение таких товаров, которые выглядят сомнительными с точки зрения дальнейшей привлекательности на рынке и подлежат переаттестации); стратегия дифференциации товара (процесс разработки ряда существенных модификаций товара, которые делают его отличным от товаров- конкурентов), стратегия диверсификации товара (производство дополнительных товаров, которые планируется предложить на новые рынки сбыта), стратегия вариации товара (основывается на стратегии повышения концентрации полезности потребительского эффекта от использования товара). Практическое значение. Исследование показателей внутреннего потенциала предприятия позволяют реально оценить внутренние сильные и слабые стороны производства, изыскать резервы, и соответственно, выбрать наиболее оптимальную ассортиментную стратегию, которая позволит предприятию сохранить уровень конкурентоспособности, а также усилить свои конкурентные позиции в отрасли. Значение/оригинальность. Полученные в ходе исследования данные способны обеспечить маркетологов исследуемого предприятия более точной информацией, полученной на основании научного подхода, что в перспективе позволит формировать эффективные ассортиментные стратегии. 